人頼誌 J. Anthrop. Soc. Nippon

94(4): $381-389$ (1986)

\title{
Anthropometry, Physical Fitness and Daily Habits with Regard to Ageing
}

\author{
Masatoshi TANAKA ${ }^{1)}$, Tadakatsu OHNAKA ${ }^{1)}$, \\ Shinya YAMAZAKI ${ }^{1)}$, Takeshi YAGAMI ${ }^{2)}$, \\ Yutaka TOCHIHARA ${ }^{3)}$ and Keiichi YOSHIDA ${ }^{4)}$ \\ 1) Department of Hygiene, School of Medicine, Showa University \\ 2) Department of 2nd Internal Medicine, School of Medicine, \\ Showa University \\ 3) Department of Physiological Hygiene, The Institute of Public Health \\ 4) Faculty of Home Economics, Jissen Women's University
}

\begin{abstract}
One thousand eight hundred male workers in an industrial factory were examined in 1981 using anthropometric measurements (height, weight, abdominal girth, chest girth, and skinfold thickness), physical fitness tests (vertical jump, hand grip force, respiratory function, and blood pressure) and a questionnaire about daily habits (cigaret smoking, alcohol consumption, and physical activity), and they were reexamined to compare in 1984.

ROHRER's indices (weight/height ${ }^{3}$ ) of the same individuals ' in 1984 were larger than those in 1981 at the 44 year old age or younger. Vertical jump, hand grip force, and forced vital capacity (FVC) declined with increasing age. FVC in 1984 declined significantly as compared with the values in 1981 at the over-30 age group. There were no remarkable differences in vertical jump between 1981 and 1984 .

The rate of non-smokers was highest at the 40-44 year age group. The rate of daily smoking in 1984 was about 60 percent which was less than that in 1981 . The rate of daily alcohol consumption in 1984 was 45 percent, which was higher than in 1981. More than 50 percent of workers over 45 years old had no regular physical activity. The rate of daily sports activity in 1984 decreased as compared with that in 1981 at each age group.

FVC and blood pressure in non-smokers were fairly good over 45 years of age. Blood pressure in non-drinkers was generally lower than in drinkers. There were definite relationships between health and daily life habits in workers, although physical fitness generally declined with increasing age.
\end{abstract}

Keywords Ageing, Anthropometry, Physical fitness, Daily habits, Blood pressure

Article No. 8606 Received April 23, 1986. 


\section{Introduction}

The ageing of the population has become a serious problem in Japan. Today, people must work till a more advanced age than in the past. It is thus important to know the physical and mental abilities and the anthropometry of older people. The ageing process brings about changes in the size and shape of the human body. These phenomena are associated with many variables such as sex, socioeconomic background, diet, health and so on. (LESSER et al., 1963; STOUDT, 1981 ; TANAKA et al., 1984 , YoKoMIZO, 1985).

Existing data about the physical ability or anthropometry of people were generally provided from cross-sectional studies, i.e. those in which a single population was studied at one point in time and the data were reported from different age groups.

In the present study, one thousand eight hundred male workers in an industrial factory were medically examined and subjected to the anthropometric measurements (body weight, height, abdomen and chest girth, skinfold thickness), physical fitness tests (vertical jump, hand grip strength, respiratory function, blood pressure, etc.), and a questionnaire about daily life habits (cigaret smoking, alcohol consumption, and athletic activities) in 1981 and 1984.

\section{Methods}

The subjects were 1,789 male workers from 23 to 58 years of age (in 1984), in an industrial factory. Eight hundred and twenty two were white-collar workers, and the remaining 967 were blue-collar workers. The number of subjects at each age group of $<29,30-39,40-49$, and $>50$ years were $131,722,701$, and 235 respectively (Table 1 ).
Skinfold thickness at the triceps, subscapula, and abdomen were measured with a Caliper (Eiken Comp.). Chest girth was measured at the nipple line at mid-tidal volume. Abdominal girth was measured at the level of the umbilicus at mid-tidal volume with the subject in the upright position. Blood pressure was measured in the left arm with the subject in the sitting position. Respiratory function was measured with an autospirometer (AS-4500 type, Minato Medical Science Co. Ltd.). The measurements were done in May, 1981 and May, 1984 using the same subjects.

\section{Results}

The values are for the same subject groups, that is, the same subjects as in 1981 were used in 1984 . Fig. 1 shows the changes in ROHRER's index (weight/height ${ }^{3}$ ) in 1981 and 1984. The values for body height were almost the same in 1981 and 1984. Therefore, the change in ROHRER's index was essentially that of the chnage in body weight. ROHRER's index tended to increase within creasing age. The index in 1984 increased significantly in the age groups of $25-29, \quad 30-34$, and $40-44$ years $(\mathrm{P}<0.01)$ compared to that in 1981. But in the 55-59 year group, it decreased significantly $(\mathrm{P}<$ 0.01 ). There were similar tendencies in the ROHRER's indices for white-collar and bluecollar workers, but the indices for bluecollar workers were higher than those for white-collar workers at 55-59 years of age.

Fig. 2 shows the changes in the abdomen to chest girth ratio (A-C ratio) for white-collar and blue-collar workers. A-C ratio increased with increasing age. The ratio for blue-collar workers tended generally to be smaller than that for white-collar workers, but there were no significant differences at 
Table 1. The numbers of white-collar workers and blue-collar workers with age in 1984 .

\begin{tabular}{lcccccccc}
\hline \multicolumn{1}{c}{ Age (year) } & $\sim 29$ & $30 \sim 34$ & $35 \sim 39$ & $40 \sim 44$ & $45 \sim 49$ & $50 \sim 54$ & $55 \sim 59$ & total \\
\hline White-collar worker & 55 & 127 & 147 & 188 & 160 & 78 & 67 & 822 \\
Blue-collar worker & 76 & 283 & 165 & 201 & 152 & 73 & 17 & 967 \\
Total & 131 & 410 & 312 & 389 & 312 & 151 & 84 & 1789 \\
\hline
\end{tabular}

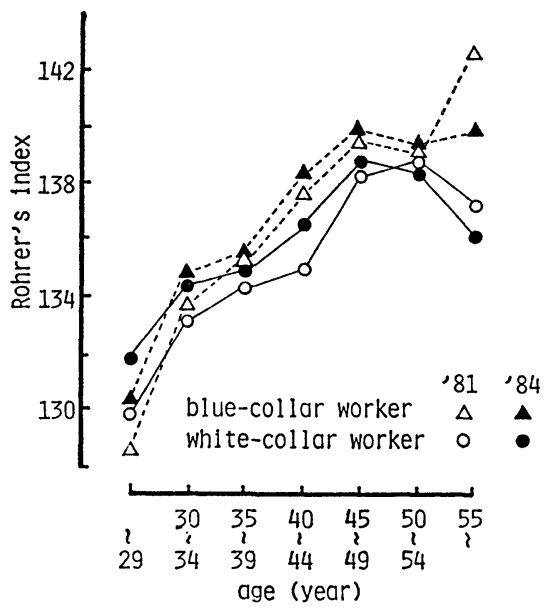

Fig. 1. The changes in Rohrer's index with age.

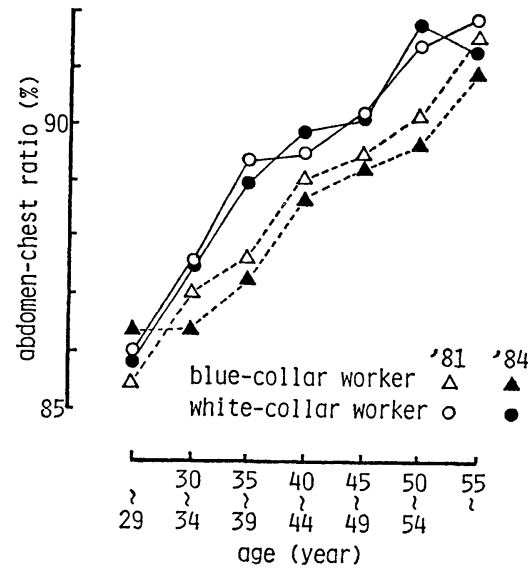

Fig. 2. The changes in abdomen to chest girth ratio with age.

each age group.

Fig. 3 shows the changes in skinfold thickness on the abdomen. The values in
1984 were larger than in 1981 at each age group. At both times, the values for white-collar workers were larger than for blue-collar workers. The changes in skinfold thickness on the subscapular area showed a similar tendency to the changes at the abdomen. The triceps measurement changed little with age.

Fig. 4 shows the values for vertical jump. The values decreased steadily with increasing age. The values in 1984 were generally higher than in 1981. There were significant differences between the values in 1984 and 1981 for blue-collar workers in the age ranges of $25-29,45-49$, and $50-54$ years and for white-collar workers in the 35-39 range $(\mathrm{P}<0.05)$. The values for white-collar workers over 35 years old where higher than those for blue-collar workers.

Fig. 5 shows the values for grip strength in the right hand. The values for bluecollar workers were higher than for whitecollar workers at less than 40 years of age. Thereafter, the values declined generally with increasing age. The values in 1981 were generally higher than in 1984: there were significant differences between the values in 1984 versus 1981 for blue-collar workers in the 30-34 age group, and for white-collar workers in the 25-29 and 45-49 year age groups $(\mathrm{P}<0.05$ and 0.01$)$.

Fig. 6 shows forced vital capacity. The values declined with increasing age. The values in blue-collar workers were slightly lower than those in white-collar workers. 


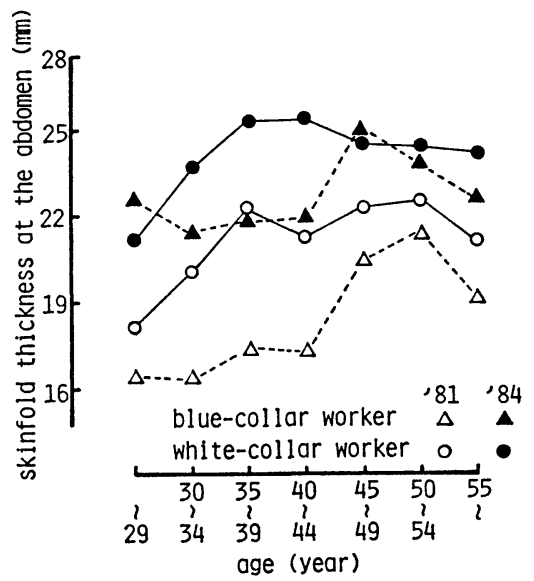

Fig. 3. The changes in skinfold thickness at the abdomen with age.

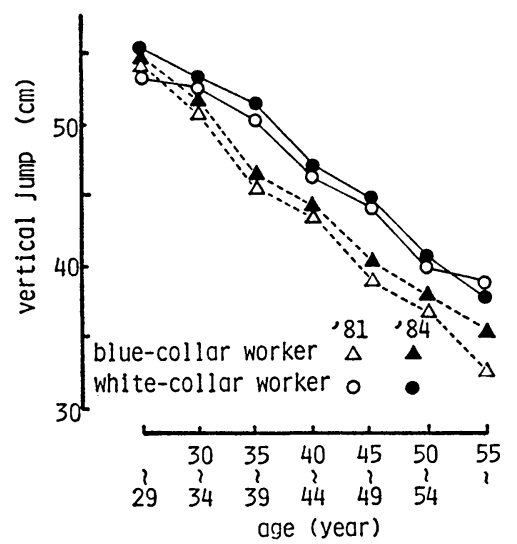

Fig. 4. The changes in vertical jump with age.

The values in 1984 were significantly lower than those in 1981 in both groups over 30 years of age $(\mathrm{P}<0.01)$.

Fig. 7 shows the changes in systolic and diastolic blood pressure with age. Systolic blood pressure in those over 50 years increased remarkably. The values in 1984 were lower than those in 1981, with especially significant declines at 25-39 years old $(\mathrm{P}<0.01)$, and at $40-44$ and $55-59$ years of age $(P<0.05)$. The values in blue-collar

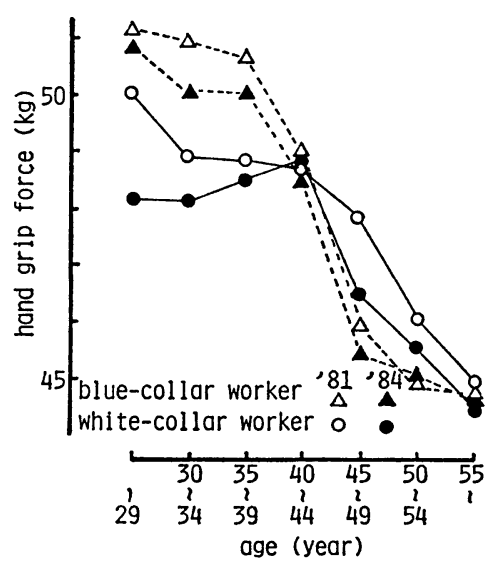

Fig. 5. The changes in hand grip strength with age.

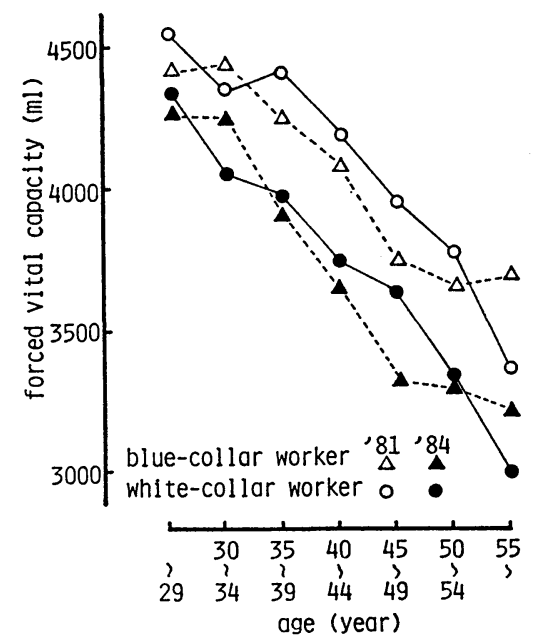

Fig. 6. The changes in forced vital capacity with age.

and white-collar workers showed similar tendencies.

Diastolic blood pressure increased gradually with increasing age. The values in 1984 were generally lower than those in 1981, with an especially significant decline in the groups of 25-34 and 55-59 years $(\mathrm{P}<0.05)$. The values of blue-collar and white-collar workers were similar. 


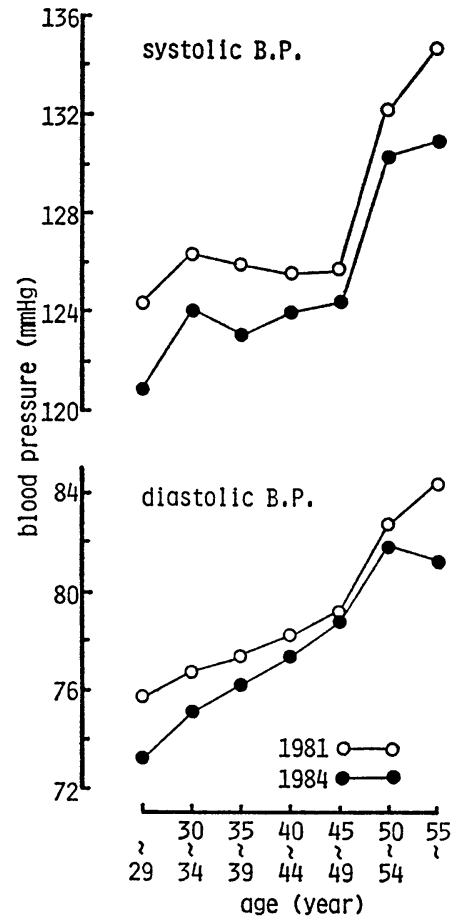

Fig. 7. The changes in systolic and diastolic blood pressure with age.
Table 2 shows the results of questionnaires about cigaret smoking, alcohol drinking and physical activity. The amount of cigaret smoking was classified into six grades; non-smoking, occasional smoking, fewer than 10 cigarets per day, 11-20, 21-30, and over 31 cigarets per day.

The rates of non-smoking in 1984 were the highest in the age group of 40-44 years : 43.2 percent. The rates of smoking over 31 cigaret per day in 1984 were the greatest in the 35-39 year group: 9.3 percent. The other age groups varied around 3-7 percent. The rate of non-smoking in white-collar workers in 1984 was 42.0 percent, which was higher than that in bluecollar workers: 32.0 percent. The rates of non-smoking in 1984 were higher than those in 1981 in both white-collar and blue-collar groups.

The level of alcohol consumption was classified into four grades : non-drinking, 1-2

Table 2. The results of questionnaires about cigaret smoking, alcohol drinking and sports activity (\%).

\begin{tabular}{|c|c|c|c|}
\hline Year & Cigaret smoking & Alcohol drinking & Sports activity \\
\hline $\begin{array}{l}1981 \\
1984\end{array}$ & $\begin{array}{r}\text { non-smoking } \\
32.0 \\
36.7\end{array}$ & non-drinking $\begin{array}{r} \\
18.2 \\
19.5\end{array}$ & $\begin{array}{c}\text { over } 3 \text { days per week } \\
27.2 \\
21.2\end{array}$ \\
\hline $\begin{array}{l}1981 \\
1984\end{array}$ & $\begin{array}{c}\text { occasional smooking } \\
3.8 \\
4.1\end{array}$ & $\begin{array}{c}\text { 1-2 times drinking per week } \\
22.9 \\
18.9\end{array}$ & $\begin{array}{c}1-2 \text { days per week } \\
19.0 \\
17.9\end{array}$ \\
\hline $\begin{array}{l}1981 \\
1984\end{array}$ & $\begin{array}{c}\text { below } 10 \text { cigarets per day } \\
6.1 \\
5.4\end{array}$ & $\begin{array}{c}\text { 3-5 times drinking per week } \\
16.4 \\
16.7\end{array}$ & $\begin{array}{c}\text { 1-2 days per month } \\
19.3 \\
17.0\end{array}$ \\
\hline $\begin{array}{l}1981 \\
1984\end{array}$ & $\begin{array}{c}\text { 11-20 cigarets per day } \\
33.6 \\
30.0\end{array}$ & $\begin{array}{c}\text { every day drinking } \\
41.5 \\
44.9\end{array}$ & $\begin{array}{c}\text { non-sports habits } \\
34.5 \\
43.8\end{array}$ \\
\hline $\begin{array}{l}1981 \\
1984\end{array}$ & $\begin{array}{c}\text { 21-30 cigarets per day } \\
18.4 \\
17.8\end{array}$ & & \\
\hline $\begin{array}{l}1981 \\
1984\end{array}$ & $\begin{array}{c}\text { over } 31 \text { cigarets per day } \\
6.1 \\
6.0\end{array}$ & & \\
\hline
\end{tabular}


times drinking per week, 3-5 times drinking per week, and daily drinking.

The rate of non-drinking in 1984 was 19.5 percent which was higher than that in 1981 . There was no difference between the rate of non-drinking for white-collar and that of blue-collar workers in 1984, and little difference among the age groups: 17-24 percent. The rate of every day drinking in 1984 was 44.9 percent which was higher than in 1981. Particularly, the rate of every day drinking was the highest in 1984 for workers 55 years of age or older, 62 percent; and the lowest in 1981 for workers 25-29 years of age, 15.5 percent.

The level of athletic or physical activity was classified into four grades: no activity, 1-2 times per month (light attivity), 1-2 times per week (medium activity), and over 3 times per week (heavy activity).

The rate of heavy activity was 21.2 percent in 1984, which was lower than that in 1981 for both blue-collar and white-collar workers. The rate of no activity in 1984 was 43.8 percent; higher than that in 1981. The rate of no activity was higher in the older age groups, and the rate of heavy activity was higher in the younger age groups.

\section{Discussion}

Many variables are related to blood pressure (OHNAKA et al., 1984): body size, obesity, body weight, age, food intake, sex, race, habits of daily life, and so on. As shown in Fig. 7, blood pressure increased with increasing age, but blood pressure levels in 1984 were lower than those in 1981. Figs. 8, 9 and 10 show the systolic blood pressure in 1984 in relation to cigaret smoking, alcohol consumption, and physical activity, respectively. The increase in blood

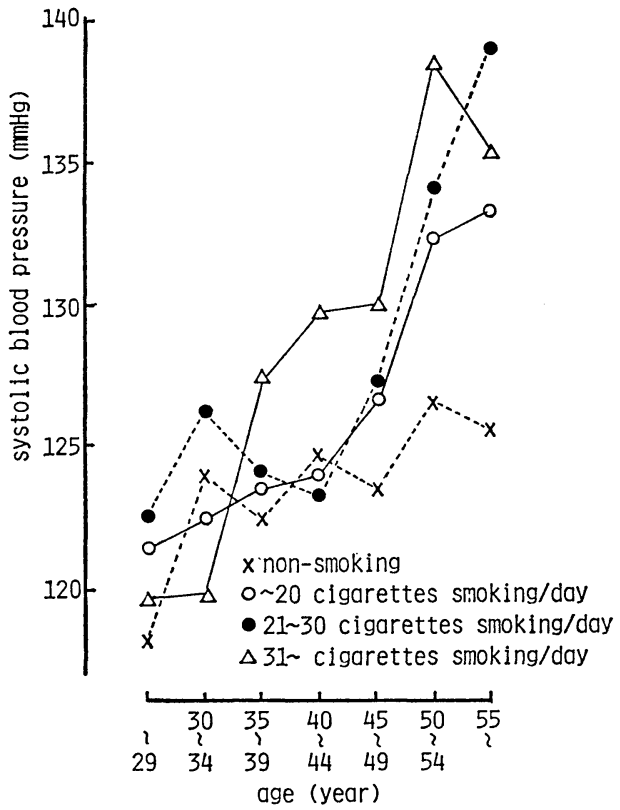

Fig. 8. The changes in systolic blood pressure with age in relation to cigaret smoking.

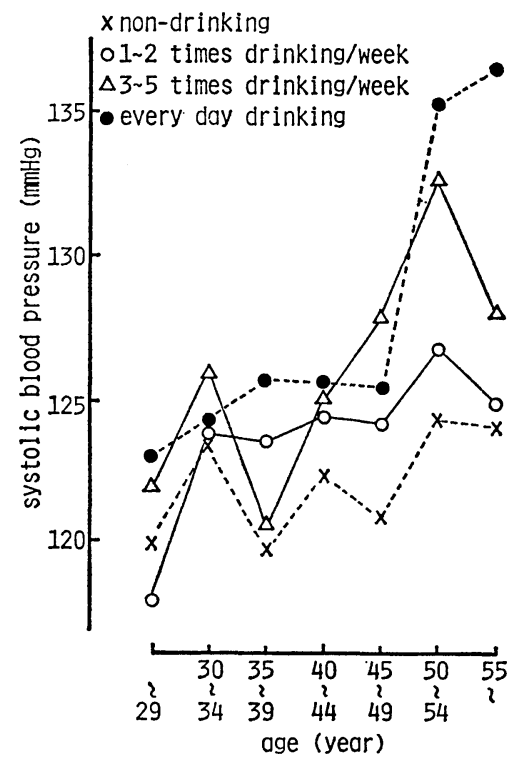

Fig. 9. The changes in systolic blood pressure with age in relation to alcohol drinking. 


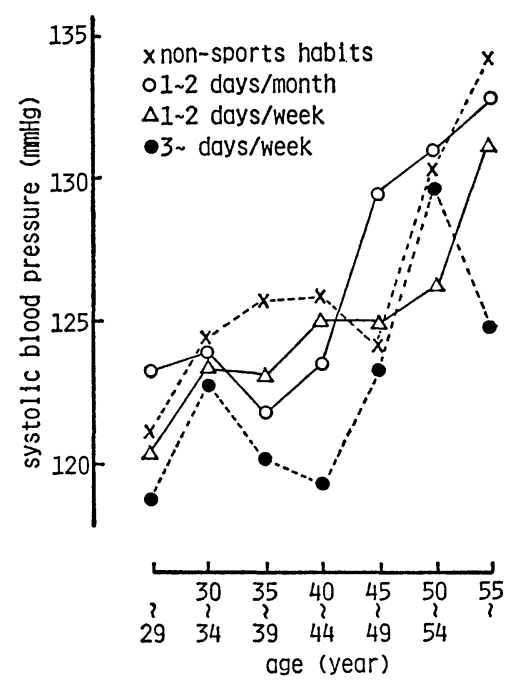

Fig. 10. The changes in systolic blood pressure with age in relation to sports habits.

pressure in non-smoking groups was smaller than in other groups. The differences in blood pressure were especially larger between smoking and non-smoking groups in those over 45 years of age. There was a similar tendency with regard to both systolic and diastolic blood pressure.

Blood pressure was generally higher in those drinking every day and lower in nondrinkers in each age group. Blood pressure in those heavily active in sports tended to be lower than in those inactive, with especially large differences at the 35-39, 40-44, and 55-59 age groups.

Certainly, blood pressure increases with increasing age; however, the degree of increase is effected by daily life habits: cigaret smoking, alcohol consumption, and athletic or physical activity. This is particularly true after middle age.

There is a profound relation between pulmonary function and the amount of dust pollution in the air in a factory (JOHNSON et al., 1985; NAGANUMA, 1984). Douglas et al. (1985) reported that the forced vital capacity (FVC) and forced expiratory volume in one second fell more rapidly in those over 40 years of age, and that cigaret smoking had a strongly harmful effect on pulmonary function in a longitudinal study of a group of firemen.

As shown in Fig. 6, FVC declined with increasing age, and the values in 1984 declined significantly in comparison with the values in 1981. Fig. 11 shows FVC in 1984 in relation to cigaret smoking. FVC in the non-smoking group tended to be slightly higher than in the smoking group, especially over 45 years of age. There was no clear relationship between FVC and the number of cigarets smoked.

SHEPHARD (1978) reported that the hand grip force of men remained relatively constant at an average of $54 \mathrm{~kg}$ from age 25 to age 45 . Thereafter, it declined by 20

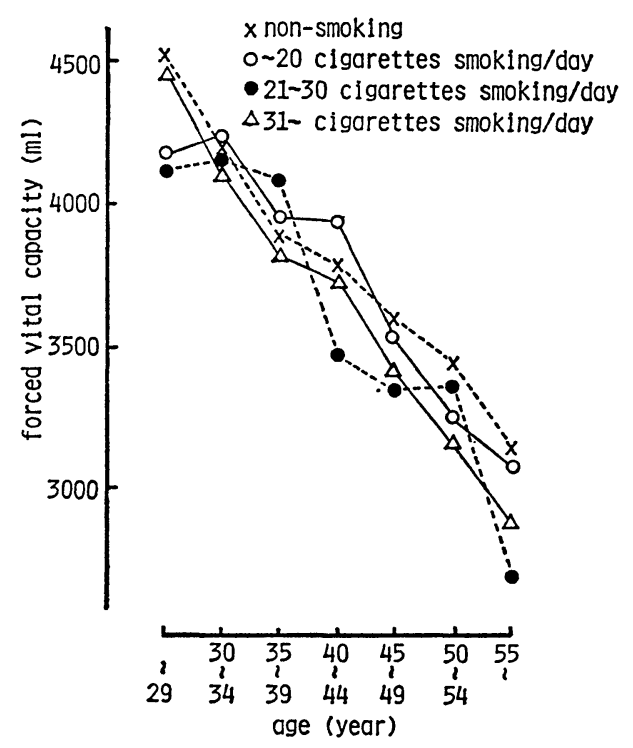

Fig. 11. The changes in forced vital capacity with age in relation to cigaret smoking. 
percent to a figure of $44 \mathrm{~kg}$ at age 65 . As shown in Fig. 5, the hand grip force of blue-collar workers from 25 to 39 years were about $50 \mathrm{~kg}$; declining thereafter to $45 \mathrm{~kg}$ at age 55, where there were no difference between blue-collar and white-collar workers.

Fig. 12 shows the values of vertical jump in 1984 in relation to physical activities. The values of each group declined with increasing age. The values of those with a habit of high physical activity tended to be slightly higher at age 49 , and the values of those with little activity tended to be lower at each age-group. Although physical fitness declined with increasing age, there were certain relationships betweed health states and daily life habits.

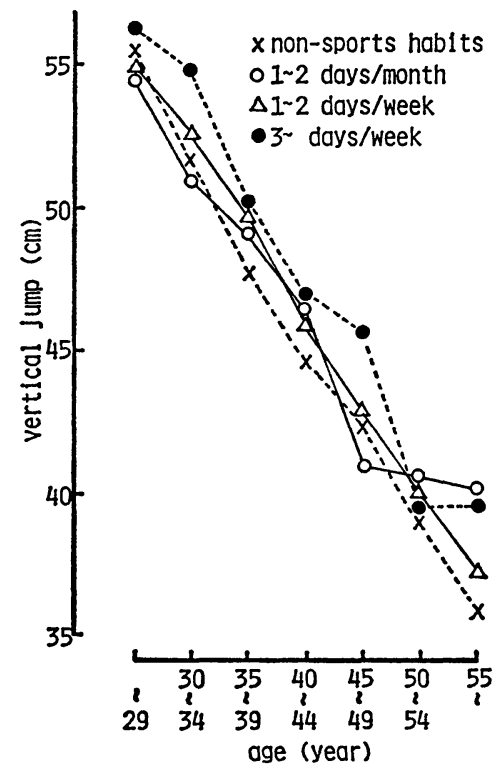

Fig. 12. The changes in vertical jump with age in relation to sports habits.

\section{Acknowledgements}

The authors thanks Dr. Richard S. WeEder, Miss Suzanne KNowlton and Miss
Atsuko IKAWA for their kind advice and editing of the manuscript.

This study was supported by a Grant-inAid of Scientific Research from the Ministry of Labor.

\section{抄録}

加齡にともなら体格, 体力, 生活習慣の変化について

田中正敏・大中忠勝・山崎信也・ 八上毫司・栃原 裕・吉田敬一

加路に伴う体格, 体力の变化を, 日常生活習慣との 関連において検討した. 被験者は同一集団, 某工場労 働者約1800名とし，1981年と1984年についての值を比 較した。

体格面では身長, 体重, 胸囲, 腹囲, 皮下脂肪厚等 を計測し，体力面では垂直跳び，握力，呼吸機能，血 圧等を測定した。生活習慣については，タバコ、アル コールや運動、スポーツなどを中心にアンケート調査 をおこなった。

計測, 測定, アンケート調査結果は, 項目や年龄に より， 3 年後において子変化の状態がことなる. 加龄 とともに呼吸機能は低下し，血圧值には上昇がみられ るが，日常の生活習慣に影響される場合も大きい。

\section{References}

Douglas, D. B., R.B. Douglas, D. OAKes, et al., 1985: Pulmonary function of London firemen. Br. J. Ind. Med., 42: 55-58.

Johnson, A., M. Chan-Yeung, L. Maclean, et al., 1985: Respiratory abnormalities among workers in an iron and steel foundry. Br. J. Ind. Med., 42: 94-100.

Lesser, G. T., I. Kumar and J.M. Steele, 1963: Changes in body composition with age. Ann. N. Y. Acad. Sci., $110:$ 578-588.

Naganuma, S., 1984: Pulmonary function test on employees exposed to factory dust. J. Showa Med. Assoc., 44 : 381-389.

OHNAKa, T., Y. Tochinara, S. Yamazaki, et al., 1984: Relationship of blood pressure to multiple personal characteristics of workers in a factory. Annals Physiol. Anthrop., 3: 297302. 
Stoudt, H. W., 1981: The Anthropometry of the elderly. Human factors, $23: 29-37$.

TANaKa, M., S. Naganuma, T. OhNaKa, et al., 1984: Living and sports habituation and phys- ical fitness of labour. J. Science of Labour., $60: 79-87$.

Yокоміzо, Y., 1985: Measurement of ability of older workers. Ergonomics, 6: 843-854.

田 中 正 敏

昭和大学医学部㦣生学教室

于 142 東京都品川区旗ノ台 1-5-8

Masatoshi TANAKA Department of Hygiene, School of Medicine, Showa University 1-5-8 Hatanodai, Shinagawa-ku, Tokyo 142, Japan 